\title{
KAJIAN GAYA VISUAL PADA NASKAH INDONESIA YANG TERDAPAT PADA BUKU INDONESIAN MANUSCRIPT IN GREAT BRITAIN
}

\author{
Yulianto Hadiprawiro, Agung Zainal Muttakin Raden \\ Program Studi Desain Komunikasi Visual \\ Fakultas Bahasa Dan Seni Universitas Indraprasta PGRI \\ J1 Nangka No. 58 C Tanjung Barat Jagakarsa, Jakarta Selatan, 12530 \\ antoberlinsma@gmail.com,agung.zmr@gmail.com
}

\begin{abstract}
Abstrak
Perpustakaan dan museum Inggris menyimpan beberapa naskah Indonesia tertua dan terpenting di dunia. Walaupun jumlahnya tidak terlalu banyak jika dibandingkan dengan yang ada pada koleksi di Indonesia , Malaysia dan Belanda, koleksi di Inggris dikenal dengan keantikan dan dalam beberapa kasus terdapat teksteks unik dan penting. Dalam buku Indonesian Manuscript in Great Britain oleh M. C Rickfels, p. Voorhoeve, dan Annabel Teh Gallop, terdapat katalog yang mencakup manuskrip bahasa Indonesia asli/ lokal (kecuali Papua), Malaysia, Brunei, Singapore dan Filipina. Dalam buku inipun terdapat katalog yang berisi manuskrip Cham dan Malagasy yang ditemukan dalam koleksi publik dari Inggris. Penelitian ini membahas tentang karakter visual yang terdapat dalam naskah asli Indonesia periode 1800-an yang terdapat dalam buku tersebut. Metode analisis estetis dipakai dengan mengungkap elemen dan prinsip visual yang diterapkan pada karakter dalam naskah Indonesia. Kajian gaya visual diharapkan dapat memperkaya khasanah perbendarahan ilustrasi dari naskah asli Indonesi
\end{abstract}

Kata kunci: Manuskrip Indonesia, Estetis, Ilustrasi, Karakter,

\section{VISUAL ANALYSIS ON THE INDONESIAN MANUSCRIPT WITHIN THE BOOK "INDONESIAN MANUSCRIPT IN GREAT BRITAIN"}

\begin{abstract}
British Library and museum collect the oldest and the most valuable Indonesian manuscripts in the world . Even though not as many as in Indonesia, Malaysia and Nedherland, these collections in Great Britain are known as the ancient antiqueness, and in some cases, unique and important text are also found. In the book of "Indonesian Manuscript in Great Britain" by M. C Rickfels, p. Voorhoeve, and Annabel Teh Gallop, there is a catalog that consists of local/ original Indonesian manuscripts, (except for Papua), Malaysia, Brunei, Singapore and the Philippines. In this book also found a catalog which contains Cham and Malagasy manuscripts which located in the British public collection. This research examined the visual character that include in the original Indonesian manuscript in the period of 1800s. Aesthetic analysis method is being used to reveal the visual elements and principles that applied to the visual characters in the Indonesia manuscript. Study of visual style is expected to enrich the preferences for illustrations of visual character from the original Indonesian manuscripts.
\end{abstract}




\section{PENDAHULUAN}

Naskah-naskah asli Indonesia Periode 1800an tertuang dalam bahasa Nusantara mempunyai beberapa keunikan tersendiri dalam gaya visualnya. Naskah yang beraksara Palawa, Kawi, bahasa Jawa, Sunda, Melayu dan Arab, dibantu pula dengan elemen estetis berupa iluminasi dan karakter visual yang tertera di sekeliling naskah tersebut. Naskah merupakan cerminan sejarah masa lalu, dan sejarah adalah separuh dari kehidupan setiap bangsa, sejarah pula yang melegitimasi kita sebagai sebuah bangsa yang besar dan patut dibanggakan (Fathurrahman, 2015:4).

Naskah merupakan bukti perdaban manusia yang hidup dalam suatu bangsa. Gaya tulisan, gaya visual dan ilustrasi yang dituangkan dalam naskah tersebut dapat menunjukkan kemajuan peradaban dalam perkembangan tulisan. Jeis kertas yang digunakan dalam penulisan naskah pun mengalami perubahan dari waktu ke waktu, mulai dari papyrus, lontar, kertas dluwang dan kertas Eropa.

Naskah tradisional Jawa termasuk naskah paling banyak se-Asia Tenggara, yang mencakup bidang dan objek yang bervariasi. (Kumar, McGlynn, 1996:161). Naskah berhubungan dengan aksara, ilustrasi, iluminasi, cap, kertas dan komponen-komponen lainnya sebagai pendukung filologi. Hal lain yang menarik dalam sisi perkembangan aksara, adalah pergeseran pemakaian alat tulis yang digunakan (Kusumah, dkk, 1997:25). Naskah-naskah tua Nusantara tersebar di seluruh wilayah Indonesia, sebagian besar ditulis dalam bahasa daerah yaitu: Melayu, Sunda, Jawa, Bali, Batak, Lampung, Bugis, Makasar, Madura (Damayanti dan Suadi, 2007:68).

Gaya visual, ilustrasi dan iluminasi yang terdapat dalam naskahnaskah koleksi museum dan perpustakaan di Inggris yang tertuang dalam buku
Indonesian Manuscript in Great Britain yang ditulis oleh M. C Rickfels, P. Voohoeve, dan Annabel Teh Gallop membuktikan bahwa senirupa di Indonesia memiliki niali estetik yang sangat tinggi. Dari karya-karya tersebut Indonesia telah memiliki peradaban yang sangat maju dalam bidang seni rupa, seperti halnya pamor yang terdapat pada tombak dan keris. Iluminasi menjadi media estetika dan sarana eksplanatory bagi teks yang terdapat dalam naskah. Iluminasi juga bisa membantu menjelaskan dari mana naskah tersebut berasal (Safari, 2011: 44). Naskah dan kehidupan masyarakat Indonesia memiliki keterkaitan tentang kehidupan dan budaya masing-masing daerah, namun masih sedikit masyarakat Indoneisa yang peduli tentang keberadaan naskah-naskah tersebut. Hal ini disebabkan adanya kesenjangan teknologi dan generasi dalam menjebatani perawatan naskahnaskah tersebut yang tersimpan secara pribadi. Banyak yang beranggapan naskah-naskah tersebut memiliki kekuatan magis. Untuk memahami wujud ilustrasi naskah lama Jawa harus dimulai dengan pemahaman masa lalu kebudayaan Jawa. Naskah Jawa dimasa lalu kebanyakan berisi ajaran kebathinan Jawa dan dikemas dalam kisah pewayangan juga merupakan analogi dengan perjuangan raja-raja dimasa itu

(Damayanti 2008; 57). Penelitian ini dibuat untuk mengkaji gaya visual yang terdapat pada buku Indonesian Manuscript in Great Britain oleh M.C. Rickfekls, p.Voor- hoeve, dan Annabel Teh Gallop, yaitu koleksi naskah lama Indnesia yang terdapat di Inggris, sehingga diketahui gaya visual yang terdapat pada naskah-naskah tersebut

\section{PEMBAHASAN}

Dalam pembahasan ini digunakan kajian gaya karakter visual, menurut 
Parker (dalam Gie, 2004:65) terdapat enam asas bentuk estetis (aesthetic form) karya seni, yaitu:

1. Asas kesatuan/utuh (The Principle of Organic Unity)

2. Asas Tema (The Principle of Theme)

3. Asas Variasi menurut Tema (The Principle of Thematic Variation)

4. Asas Keseimbangan (The Principle of Balance)

5. Asas Perkembangan (The Principle of Evolution)

6. Asas Tata Jenjang (The Principle of Hierarchy)

Berdasarkan data literatur

Indonesian Manuscript in Great Britain, masing-masing naskah akan ditelaah secara estetis, terutama secara asas-asas prinsip desain. Dari segenap naskah yang didokumentasikan dalam buku itu, sekitar 7 naskah yang mengandung wujud figur karakter visual dan akan dibahas dalam penelitian ini. Berikut adalah daftar naskah yang akan dibahas dari dokumen tersebut, antara lain:

1. Naskah Serat Sela Rasa 1, tertulis dalam dokumen: Fig. 3. Serat Sela Rasa in Javanese, British Library, MSS jav 28, f.19v (hal. 61).

2. Naskah Serat Damar Wulan, tertulis dalam dokumen Fig.4. Serat Damar Wulan In Javanese, British Library, MSS jav 89, f.5r (hal. 71).

3. Naskah Serat Sela Rasa 2, tertulis dalam dokumen: Fig.5. Serat Sela Rasa in Javanese British Library, MSS jav 28, f.49r (hal. 61).

4. Naskah Figur Wayang 1, Tertulis dalam dokumen: Fig. 6. Javanese album of coloured figures from the wayang. British Library, Or.9333, f. $8 v$ (hal. 54).

5. Harimau, Tertulis dalam dokumen: Fig 11. Drawing of a tiger from usada, Balinese medical text. British Library, Or. 16801, ff. 60v-61r (hal. 270).
6. Naskah Pustaka Batak, Tertulis dalam dokumen: Fig. 13. Batak pustaka, Containing instructions on controlling forces by invoking the supernatural. Britsh Library, Or. 14808, f. A 20 (hal 273).

7. Kartu main Bugis, Tetulis dalam dokumen: Fig.15. Pack of playing cards, with Buginese text on reverse. British Museum. As 8171, a-ay (hal. 277).

Berikut adalah tampilan karakter visual yang terdapat pada naskah Indonesia dalam buku Indonesian Manuscript in Great Britain:

\section{Naskah Serat Sela Rasa 1}

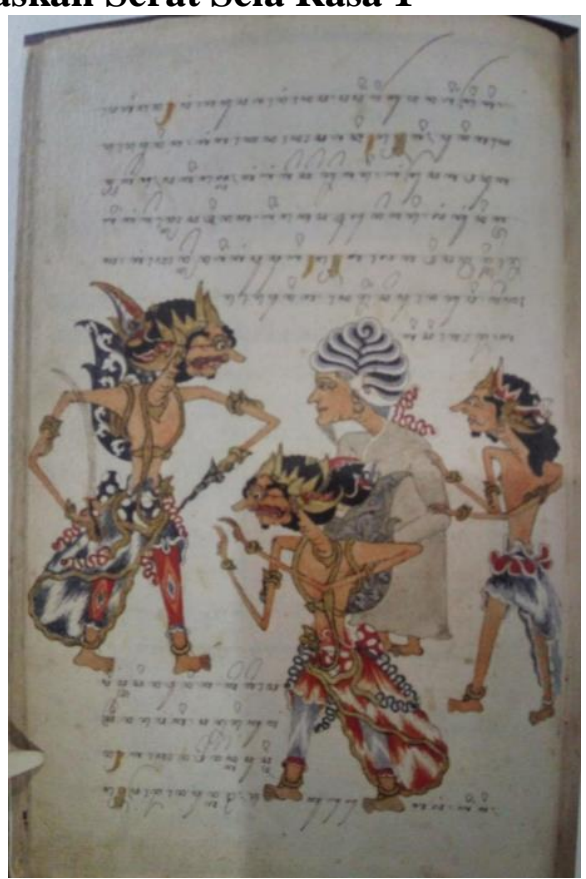

Gambar 1.1 Naskah Serat Sela Rasa 1 (Sumber: Ricklefs, 2014)

Serat Rasa, Tertanggal 24 Sapar 1731 (Tahun Jawa) / 4 Juni 1804 Masehi. Pemilik asli Naskah dan Dokumen tercantum dalam halaman pertamanya: Puniko serat kagunganipun nyonya Sakeber (Gezaghebber, atau kemungkinan juga Madame Schaber dari Surabaya).

Asas kesatuan

Pada Gambar 1.1 terdapat tulisan dengan huruf seperti Kawi tipis miring 
dan bentuk 4 wujud figur. Figur tersebut terdiri dari 3 menyerupai wayang, dan 1 meyerupai manusia. Elemen warna coklat krem muda dan emas terdapat dalam pewarnaan 4 figur dan dalam teks naskah, menjadikan gambar ini satu kesatuan yang utuh.

\section{Asas Tema}

Wujud wayang yang satu terletak di sebelah kiri menghadap ke kanan memegang keris di tangan kiri, dan pedang di tangan kanannya. Di sebelah kanan dan bawah tengah terdapat 2 wayang lagi menghadap ke kiri dengan tangan sedikit di depan muka masing-masing seolaholah ingin mengingatkan sesuatu terhadap wayang lain. Di sebelah kanan sebagai latar terdapt figur berwujud lakilaki berjanggut putih bersorban berwana hitam dan putih, dan jubah panjang seperti gamis, ia menyerupai seorang kyai. Titik fokus naskah ini terlihat pada gambar 4 figur tersebut karena teks yang ada seperti mengisi ruang kosong setelah gambar dibuat.

\section{Asas Variasi menurut Tema}

Terdapat variasi yang dikembangkan dalam naskah di atas, seperti jeda warna emas dalam teks, variasi fashion yang dikenakan oleh figur-figur yang ada. Dua figur memakai kain abu-abu bertekstur semu garis-garis putih, lalu pada satu figur yang lain berwarna merah bertekstur garis putih, dan fashion pada satu figur tampak polos berwarna putih keabu-abuan.

\section{Asas Keseimbangan}

Kesemua karakter figur yang digambarkan ditempatkan secara asimetris, namun teteap harmonis. Walaupun berlawanan dengan kemiringan teks yang ada, tapi justru membuat komposisinya tidak monoton. Asas Perkembangan Perkembangan yang cukup unik secara teknik pensil dan cat air.
Asas Tata Jenjang

Secara tata jenjang, terlihat fokus utama adalah figur di sebelah kiri karena merupakan satu-satunya yang digambarkan paling besar, bersenjata keris dan pedang. Dari alur membaca kiri ke kanan secara visual menggiring mata untuk melihat ke arah 3 figur lainnya di sebelah kanan, dari figur guru atau kiyai,ke figur wayang yang di bawah lalu ke wayang yang paling kecil di sebelah kanan.

\section{Naskah Serat Damar Wulan}

Damar Wulan, merupakan awal dari penaikan tahta putri Brawijaya (Kusuma Kancana Wungu) dalam kerajaan Majapahit. Tertanggal JumahatManis, 9 Rabingulawal, namun tanpa tahun. Diilustrasikan secara berwarna dan mengkilat, walau secara artistik tidak terlalu baik namun penyelesaiannya cukup menarik. Bahan kertas Eropa, berukuran $25,5 \mathrm{~cm} \mathrm{X} 20 \mathrm{~cm}$, warna naskah agak kotor.

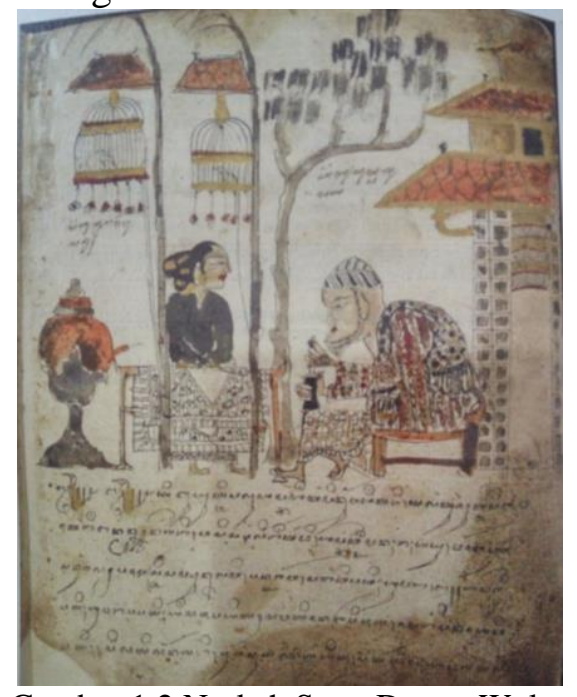

Gambar 1.2 Naskah Serat Damar Wulan (Sumber: Ricklefs, 2014)

\section{Asas Kesatuan}

Pada gambar 1.2 yang merupakan naskah Serat Damar Wulan, terdapat elemen garis-garis yang cukup tegas. Nuansa warna kecoklatan dengan aksen merah gelap atau coklat tua pada beberapa objek bentuk yang digambar 
secara manual. Ada beberapa bentuk objek yang dipadukan dengan teks seperti huruf kawi kuno.

Asas Tema

Dua figur dalam gambar ini digambarkan dengan wujud seorang wanita berbaju abu-abu gelap, memakai bawahan kain yang terhalang seperti jembrengan kain batik didepannya. Sosok ini berambut hitam berkonde menghadap ke kanan. Posisi berdiri di balik jemuran itu terletak di belakang dua garis vetikal melengkung di atas membentuk tiang penyangga 2 sangkar burung yang unik. Jeruji sangkar burung digambarkan dengan garis sederhana berwarna hitam tipis, dengan aksen warna kuning kecoklatan dan merah, dengan hiasan di bawahnya memakai garis-garis pendek dengan bandul-bandul merah. Di atas sangkar burung juga ada tudung pelindung yang berbentuk seperti atap rumah dari samping, bertekstur semu membentuk susunan genteng lonjong atau sirap berwarna merah kecoklatan. Pada sisi tengah gambar terdapat sebuah pohon kering berdaun jarang berwarna coklat keabuan. Gamabr Pohon terletak di belakang jemuran kain. Di sisi kanan pohon terdapat figur kedua. Figur ini nampak seperti pria berjanggut dan cambang tipis. Sosoknya digambarkan sedikit lebih besar dari sang wanita, sedang duduk tampak samping di atas dipan coklat, tangan kanan memegang benda hitam silinder seperti gelas atau tabung dengan tutup kecil hitam di tangan kirinya. Figur pria ini memakai kupluk atau peci bermotif garis-garis pendek berwarna hitam dan putih, berbaris diagonal dari kiri atas ke kanan bawah, dan di atasnya garis diagonal hitam putih degan arah diagonal berlawanan. Baju yang dikenakannya bermotif garis-garis dan bulat-bulat berwarna merah, hijau, kuning kecoklatan, membentuk pola batik. Bawahannya berupa kain seperti sarung bermotif garis membentuk kotakkotak dengan motif bunga. Pada sisi paling kanan naskah terdapat potongan sisi rumah sebagai latar. Rumah tidak digambarkan secara utuh, hanya sebagian saja seperti dibutuhkan untuk mengisi ruang kosong. Rumah digambarkan dengan atap bertingkat tiga. Dari paling atas atap pertama dibuat sedikit kecil, berwarna kecoklatan dengan atap berwarna merah. Pada atap kedua dibuat berwarna merah gelap bertekstur. Di tengah bawah terdapat bidang kotak berwarna hitam seperti jendela, dengan dinding berwarna krem kecoklatan. Atap ketiga dibuat lebih besar dan berwarna merah kecoklatan dan sedikit lebih terang dari atap satu dan kedua. Di bawahnya terdapat dinding vertikal. Dinding tidak berwarna polos, melainkan berpola kotak-kotak putih dengan di tengahnya berwarna coklat, seperti keramikatau batu alam. Ada juga tekstur pola pada dinding berupa garis lengkung berwarna coklat dan garis-garis vertikal pendek. Pada sisi kiri gambar terdapat bentuk semacam guci air berwarna merah kecoklatan yang memiliki satu kaki seperti pot besar.

Kemungkinan tematik yang diangkat dalam gambar ini adalah saat santai suatu hari di pekarangan rumah. Cerminan potongan kehidupan sehari-hari disajikan dengan sederhana, apa adanya.

Asas Variasi menurut tema

Kegiatan yang ditunjukkan pada gambar ini kemungkinan diatur antara pagi sampai menjelang sore, dilihat dari masih tergantungnya sangkar burung dengan burungnya di atas tiang, karena pada umumnya burung dimasukkan ke dalam rumah atau diturunkan setelah waktu magrib tiba sampai pagi hari.

Asas Keseimbangan

Keseimbangan asimetris yang diterapkan pada gambar atau dengan 
komposisi gambar dua pertiga bagian halaman dan sepertiga halaman teks.

Asas Perkembangan

Secara teknis pengembangan teknik penggambaran karakter manusia digambarkan masih dekat dengan dimensi wayang. Wajah digambarkan dari sisi samping, mata tampak depan, bahu sang wanita digambarkan tampak depan, namun figur pria digambarkan tampak samping semua. Dimensi ruang sedikit menganut perspektif satu titik hilang. Jika dilihat dari ukuran dan posisi, figur pria, dua tiang sangkar burung dan guci digambarkan paling depan. Lalu berikutnya wanita dan jemuran kain batiknya, kemudian di belakangnya adalah pohon dan rumah.

\section{Asas Tata Jenjang}

Secara hirakis alur mata membaca gambar ini dari atas ke bawah, karena gambar diposisikan di atas teks, maka pandangan berikutnya setelah melihat gambar, mata akan tertuju pada teks dengan huruf kawi kuno yang tersusun lima baris. Jika naskah ini dibuat pada kertas, nampak seperti bertekstur sedikit kasar.

\section{Naskah Serat Sela Rasa 2}

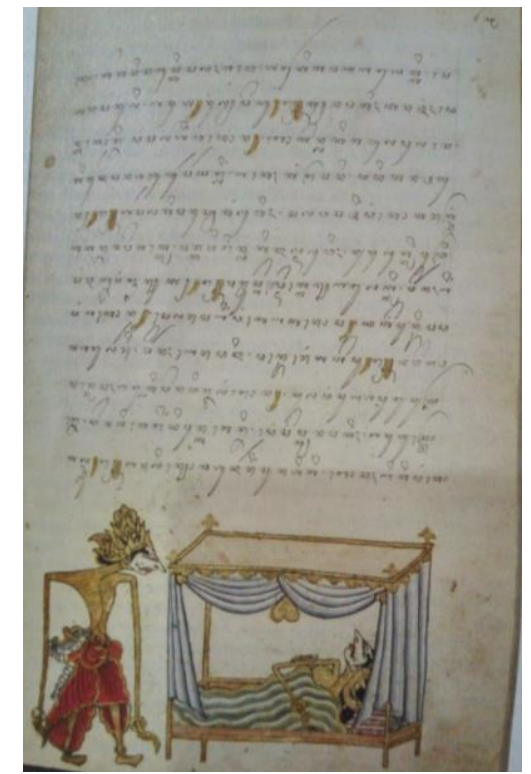

Gambar 1.3 Naskah Serat Sela Rasa 2 (Sumber: Ricklefs, 2014)

\subsection{Asas Kesatuan}

Unsur-unsur pembentuk gambar pada gambar 1. 3 berupa garis-garis tipis, dipadukan dengan warna coklat keemasan, merah dan garis biru-putih dan garis hijau-putih. Terdapat dua figur manusia berbentuk wayang di sisi sepertiga halaman pada naskah ini. Satu figur berpose berdiri dengan wajah mengarah ke kanan. Di kepalanya ia mengenakan semacam mahkota dengan garis lancip bertingkat, kemungkinan berupa mahkota raja atau pangeran. Paras wajah berwarna putih dengan bentuk hidung lancip, sedikit panjang. Bermulut merah dan berkumis panjang melingkar, kemungkinan dibuat untuk menunjukkan karakter pria. Dengan warna badan kecoklatan bertelanjang dada, seperti layaknya wujud wayang kulit pada umumnya. Posisi badan dari bahu sampai sekitar perut dibuat tampak depan. Tangan memanjang lurus sampai mendekati kaki. Tangan memakai gelang berwarna kecoklatan juga serupa dengan warna kulit badannya. Jari tangan dibuat merapat lengkung ke bawah. Di belakang pinggang terdapat garis dan bidang lengkung menyerupai keris. Garis-garis melengkung lain membentuk kurva berwarna abu-abu di sekitar pinggang belakang. Figur ini mengenakan kain menyerupai sarung berwarna merah berserat garis hitam, dengan garis pinggir berwarna emas mengelilingi sisi sarung merahnya. Pada area pinggang dan bawah perut terdapat bentuk bulat-bulat tak beraturan menyerupai lipatan sarung.

Figur ke-2 di sisi kanan berpose berbeda. Ia digambarkan dengan posisi wajah menengadah dengan pose tiduran. Berparas wajah berwarna putih berhidung lancip agak panjang, berbibir merah. Pada kepalanya tidakterlihat utuh terbuka, karena terhalang garis abu-abu putih menyrupai tirai kelambu berlipat. Wujud badanpun tidak terlihat utuh. 
Yang terekspos hanya bahu kanan dan tangan kanan menekuk ke arah bawah. Bagian dada kanan terlihat lebih membulat ke atas dari figur pertama, sehingga kemungkinan karakter ini adalah wujud wanita. Satu sisi dada dan bahu kiri tidak terlihat, karena tertutup bidang kurva bergelombang sepanjang badannya berwarna hijau belang-belang putih menyerupai selimut. Ia berpose di sebuah tempat tidur berkelambu abu-abu belang-belang putih, dengan ornamen dekoratif di sekeliling atap tempat tidurnya. Kasur atau alas ia berbaring berwarna putih bergaris ganda berwarna merah secara horisontal dengan diisi garis garis lengkung megisi ruang kosong berselang putih.

\section{Asas Tema}

Tematik yang diangkat dalam naskah Serat Sela Rasa ini kemungkinan berupa hubungan pria-wanita atau suami istri. Suasana intim pasangan suami istri sebelum memadu cinta, kemungkinan merupakan malam pertama sepasang pengantin.

\section{Asas Variasi menurut Tema}

Variasi cerita mungkin diangkat dengan pose yang tidak biasa, karena wujud wayang kulit dalam cerita pada naskah ini digambarkan secara manusiwai sekali. Dengan pose-pose dan properti yang menunjukkan aktivitas manusia pada umumnya. Penggambaran tempat tidur dibuat dengan perspektif satu titik hilang.

\section{Asas keseimbangan}

Secara keseluruhan, keseimbanagan asimetris yang diterapkan dalam naskah Serat Sela Rasa ini terlihat pada komposisi gambar yang ditempatkan pada 1/3 halaman yang ada. Dua pertiga dari halaman naskah ini berisi huruf Jawa Kawi yang tersusun rata kiri-kanan. Beberapa aksen dimunculkan dengan warna keemasan pada beberapa teks. Pada gambar, posisi figur wayang yang berdiri diletakkan di sebelah kiri bawah halaman berukuran sepertiga bagian dari lebar halaman, sedangkan posisi figur wayang ke-2 yang berpose tiduran di atas ranjang berkelambu abuabu putih, berukuran dua pertiga lebar halaman naskah.

Asas Perkembangan

Perkembangan makna secara interpretasi dari penggambaran dua figur wujud wayang yang meyerupai pria dan wanita ini bisa mengarah kepada makna sakral suatu hubungan, romantisme, atau konflik antara fisik dan batin.

\section{Asas Tata Jenjang}

Secara hirarkis ketika melihat naskah ini, mata akan tertuju pada warna paling kuat di sini yaitu warna merah yang menempel pada figur satu, pada sisi kiri bawah halaman, dan karena wajahnya menengok ke kanan, maka kemudian mata akan "digiring" ke figur ke-2. Figur ke-2 dengan dominasi garis-garis dan wana belang menghadap ke atas seolaholah mengarahkan pembaca untuk membaca isi teks pada naskah. Alur baca huruf $\mathrm{C}$ terbalik atau berkelanjutan berputar melawan arah jarum jam sepertinya dimunculkan dalam naskah ini.

\section{Naskah Figur Wayang 1}

Dalam naskah pada Gambar 1.4 tertulis dalam dokumen: Fig. 6. Javanese album of coloured figures from the wayang. British Library, Or.9333, f. 8v (hal. 54). 


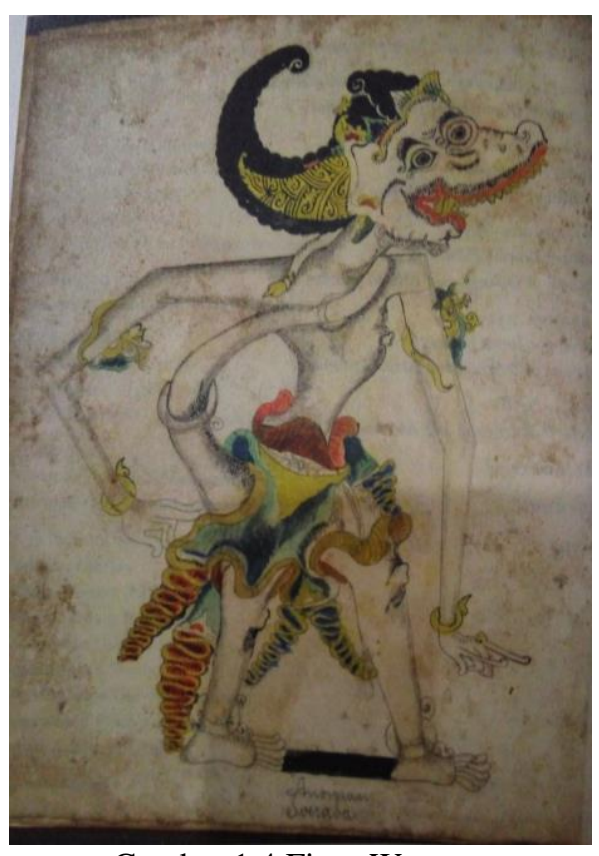

Gambar 1.4 Figur Wayang

(Sumber: Ricklefs, 2014)

Berikut ini adalah penjabaran secara estetisnya:

Asas Kesatuan

Secara keseluruhan figur wayang ini menyerupai tokoh Anoman. Wujud Kera Putih dengan kesaktian dan sifat jujur Hal ini tercermin pada warna kulit badan wayang berwarna putihdari kepalaingga kaki. Pose penggambaran figur dibuat berdiri tegak, sebagaimana wayang kulit berdiri. Kepala sedikit menengadah ke atas kanan. Pada wajah terlihat multi dimensi, karena kedua mata dan hidung muncul seperti tampak 3/4 wajah, namun bagian mulut digambarkan sedikit memanjang tampak samping di mulut bagian atas, dan memendek di mulut bagian bawahnya. Mulut figur ini digambarkan bergeligi agak tajam dan bertaring, berbibir merah dengan garis tepi hitam.

Bagian dagu terdapat garis-garis melingkar berkumpul seolah-olah membentuk semacam jenggot keriting tipis. Walau terlihat wujud seperti wayang kulit namun penyelesaian karya wayang digoreskan warna gradasi untuk membentuk dimensi volume, khususnya nampak pada bagia leher, sebagian bahu, tangan, badan dan buntut. Konsep manusia kera mengekspos buntut dari belakang melingkar ke bagian leher dari sisi depan dada. Pada tangan Bentuk gelang Pada lengan atas kiri dan kanan dilingkari bentuk kurva menyerupai ular naga kecil berwarna hijau muda bersayap biru. Pada pinggang terdapat bidang kurva organis tak bersudut berwarna merah kecoklatan. Bidang lain di bawah terdapat goresan warna biru hijau bercapur dengan sisi berwarna kuning dengan tekstur garis-garis, menyerupai kain berlipat-lipat. Bagian lutut dibuat membulat seperti tulang tempurung lutut manusia dilengkapi arsiran bayangan sedikit tebal dari bayangan pada kulit putih pada kaki dan badan. Walau kaki berjajar ke samping, namun jari-jari kaki disusun seperti tampak atas.

\section{Asas Tema}

Pose jari tangan yang tidak santai menunjukkan kesan kebijaksanaan, tematik memamerkan wujud profil karakter wayang Anoman Soeraba. Figur Anoman Soeraba dipertegas dengan teks yang tertulis di bawah kaki.

\section{Asas Variasi Menurut Tema \\ Variasi yang ada dari karakter} figur wayang Anoman ini tidak digambarkan dengan kain poleng hitam putih, namun dimunculkan dengan bentuk kainmerah, kuning, hijau kebiruan, dan sedikit aksen merah bergaris kuning. Pada beberapa bentuk wayang kulit yang ada pada umumnya buntut Anoman ditempelkan sejajar dengan mahkota yang melengkung ke atas di belakang kepala, namun di sini tidak. Buntut dengan ujung bulu berwarna kuning, dililitkan mengelilingi lehernya.

Efek goresan pensil terlihat pada beberapa garis tepi dan arsiran bayangan. Penggunaan media lain kemungknan seperti cat air juga dipakai di sini. Efek 
latar kecoklatan mungkin dari kusamnya kertas merang.

\section{Asas Keseimbangan}

Dilihat dari komposisi figur pada area naskah yang didokumentasi terlihat komposisi terpusat di tengah atau centered. Satu figur besar di tengah halaman membentuk kesimbangan asimetris, karena pose berdiri tampak depan namun kepala menengok ke samping kanan.

\section{Asas Perkembangan}

Penggambaran sudut pandang multi dimensi atau ruang waktu datar untuk figur wayang memang menjadi ciri khas setiap karakter. Perkembangan yang cukup unik ditampilkan dengan kesan bervolume khususnya pada area tubuh, tangan dan buntut dengan diberi efek arsiran dan bayangan sehingga nampak realistis, tidak seperti wayang kulit.

\section{Asas Tata Jenjang}

Dimensi warna dan bentuk dalam figur wayang pada naskah ini didominasi warna putih dengan aksen warna kuning secara konsisten mengisi latar ornamen pada mahkota, taring gigi, gelang lengan berbadan ular, gelang tangan, kain pada area bawah pinggang dan sepanjang tepi kain yang menjuntai sampai ujung bawah kaki kiri.

\section{Naskah Figur Harimau}

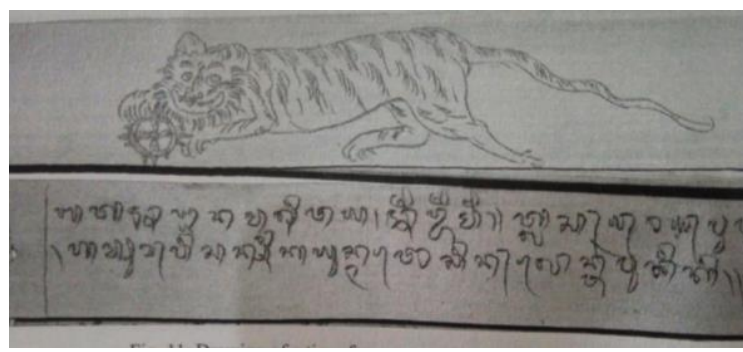

Gambar 1.5 Naskah Figur Harimau

(Sumber: Ricklefs, 2014)
Dalam Naskah Figur Harimau Tertulis dalam dokumen Fig 11. Drawing of a tiger from usada, Balinese medical text. British Library, Or. 16801, ff. 60v61r (hal. 270)

\section{Asas Kesatuan}

Unsur-unsur pembentuk gambar figur harimau dibuat dengan garis-garis sederhana. Nampak seperti goresan pensil pada garis tepi karakter visual berbentuk menyerupai harimau. Bulu belang diselesaikan dengan arsiaran garis putus-putus. Walau sedikit tidak terlalu proporsional, namum pesan dan kesan bahwa ini adalah gambar harimau dapat ditangkap. Kedua kaki depan Harimau nampak didekatkan pada satu benda bundar menyerupai kemudi kapal berukuran kecil atau seolah-olah sedang memberi kendali atau bermain.Warna yang diterapkan pun sederhana hitamputih. Wajah Harimau yang agak tak lazim seperti hewan justru diberi eksprasi seperti wajah manusia senyum.

\section{Asas Tema}

Dari dokumen yang ada, naskah ini merupakan catatan atau tulisan tentang pengobatan dari Bali. Usada disebutkan di sini adalah sebagai perawatan medis. Ada pula beberapa kemungkinan secara tematik yang bisa diangkat jika melihat wujud figur dalam gambar dan posisi teks atau huruf-huruf yang ada sedikit bergaya humorik kartunal, karena harimau digambarkan tidak secara realis.

\section{Asas Variasi menurut Tema}

Lekukan-lekukan garis pada badan dan wajah harimau serupa dengan tarikan garis yang ada pada teks di bawahnya.

Asas keseimbangan

Keseimbangan simeteris horisontal lebih tersa dalam naskah ini 
karena komposisi gambar dan teks seimbang. Porsi ukuran gambar dan ukuran teks yang terlihat 2 baris cukup sama besar.

\section{Asas Perkembangan}

Perkembangan karakter hewan yang dibuat sederhana namun berkarakter lucu, ada rasa "bermain" dalam penciptaan karyanya. Modifikasi tata letak teks yang sedikit dibatasi garis vertikal di sisi kiri dekat dengan jilid tali atau akar di pinggir bidang seolah-olah seperti mempertegas bahwa adanya margin yang terpikirkan.

\section{Asas Tata Jenjang}

Posisi Gambar diletakkan di atas tekssehingga membantu mata pembaca untuk mengikuti alur membaca dari atas ke bawah. Ditampilkan pada dua bidang terpisah seperti bambu atau kertas tebal yang pada sisi kirinya seperti dijilid secara tradisional menggunakan tali atau akar.

\section{Naskah Pustaha Batak}

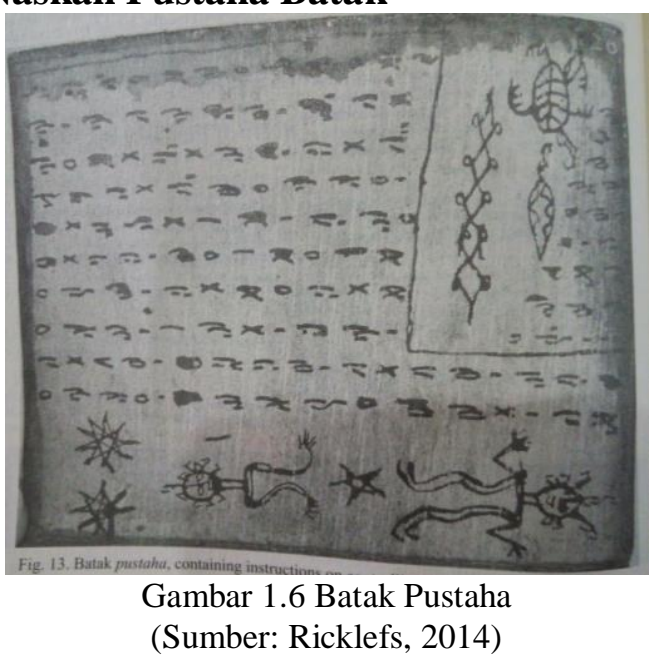

Pustaha Batak yang didokumentasikan ini berisi instruksi atau semacam petunjuk untuk mengatur beberapa kekuatan untuk menghimpun arwah-arwah gaib. Pustaha, sangat jelas bahwa naskah ini kemungkinan milik marga Simalungun. Dalam dokumen tertulis Fig. 13. Batak pustaha, Containing instructions on controlling forces by invoking the supernatural. Britsh Library, Or. 14808, f. A 20 (hal 273).

\section{Asas Kesatuan \\ Unsur-unsur pembentuk tata letak dalam naskah menggunakan garis-garis terbatas pada warna monokrom hitam- putih, tarikan garis tegas, bentuk-bentuk huruf menyerupai aksara Batak Kuno.}

Asas Tema

Tematik pada naskah menggunakan bahasa-bahasa berupa kode-kode simbolik. Wujud karakter visual digambarkan mengisi ruang kosong berdimensi Ruang Waktu Datar. Proposional figur tidak digambarkan dengan wujud zmanusia utuh, namun merupakan hasil stilasi bentuk garis-garis kurva organis.

Asas Variasi menurut Tema

Ada kemungkinan unsur bentuk figur stialtif yang tidak membentuk manusia utuh bisa diinterpretasikan sebagai mahluk selain manusia. Tematik sakral-mistis bisa jadi variasi tematik dalam naskah.

\section{Asas keseimbangan}

Kesimbangan yang diterapkan pada naskah ini adalah kesimbangan Komposisi yang dipakai adalah $2 / 3-1 / 3$ secara asimetris atau informal.

\section{Asas Perkembangan \\ Komposisi unik memunculkan tata letak yang tidak biasa. Dominasi garis-garis horisontal pada kode gambar sebagai simbol dan kode teks berupa garis-garis dilawan dengan satu bidang kotak sebelah kanan atas sebagai aksen penarik perhatian.}




\section{Asas Tata Jenjang}

Jika dilihat dari bentuk komposisi tata letak yang ada, simbol-simbol huruf yang horisontal menggiring mata untuk menuju ke bagian kanan naskah kepada garis yang membentuk bidang kotak di sisi kanan. Setelah itu turun lagi ke sisi kanan bawah pada bentuk bintang atau yang menyerupai matahari, lalu berakhir ke sisi kanan bawah pada bentuk dua figur manusia stilatif.

\section{Kartu main Bugis}

Kartu main Bugis ini dalam dokumen tertulis dalam dokumen: Fig.15. Pack of playing cards, with Buginese text on reverse. British Museum. As 8171, aay (hal. 277)

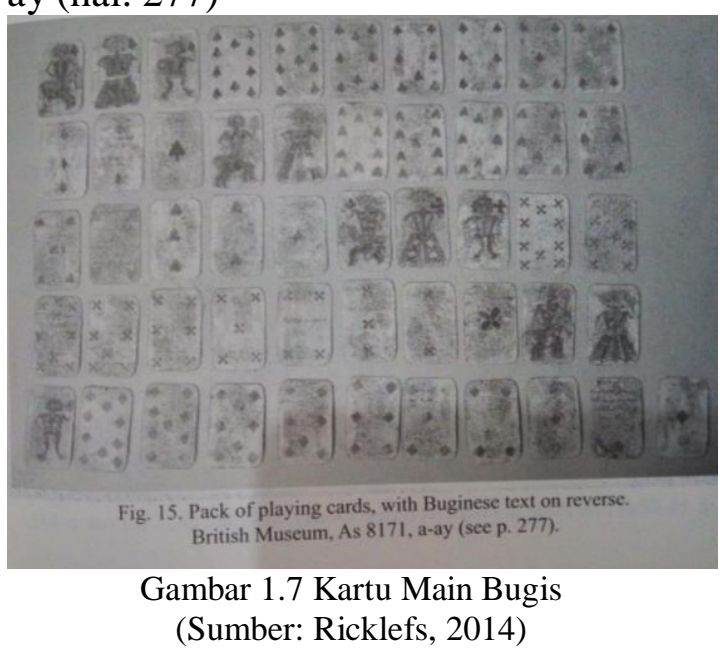

Asas Kesatuan

Komponen visual yang terdapat dalam kartu, dibagi berdasarkan sisisisinya. Kemungkinan kartu ini memeliki 2 muka yang berbeda-beda. Kartu yang didokumentasi terdapat 51 buah. Bentuk gambar di dalamnya: wajik, daun cengkeh, bentuk hati terbalik dan sebagai garis $\mathrm{X}$ atau silang.

\section{Asas Tema}

Keceriaan, nafas permainan, nuansa tidak formal tercermin dalam tematik kartu main dari Bugis ini.
Asas Variasi menurut Tema

Variasi yang unik dalam tematik permainan ini adalah wujud figur Raja, Ratu dan Prajuritnya. Setidaknya yang terlihat dalam dokumetasi, walau hanya satu sisi dan tidak terungkap dalam gambar ini sisi lain yang kemungkinan berisi bahasa daerah Bugis.

\section{Asas Keseimbangan}

Di luar tokoh atau figur karakter, angka dan gambar objek terdapat teks pada kartu dengan dua sisi muka. Keseimbangan formal kemungkinan diterapkan pada tata letak kartu permainan ini.

\section{Asas Perkembangan \\ Sangat tidak disangka adanya} kartu bermain yang dilengkapi Bahasa Bugis di setiap kartu. Hal ini menjadi cukup unik, kemungkinan adanya interaksi atau sosio-respon dari kaum lokal mengadaptasi permainan dari budaya asing.

\section{Asas Tata Jenjang}

Kartu bermain dari Bugis ini kemungkinan dibuat pada dua sisi. Sisi muka ditampilkan dengan gambar karakter raja, ratu, prajurit, dan objek bentuk wajik, garis silang, daun cengkeh dan bentuk hati terbalik. Kemudian sisi belakang yang kemungkinan berisi teks berbahasa Bugis. Penggambaran Karakter visual yang ada tidak dibuat mirroring, jadi posisi pembaca atau pemain dapat melihat komposisi alur membaca gambarnya dari atas ke bawah.

\section{KESIMPULAN}

Naskah Indonesia yang tersusun dari wujud karakter visual dan teks serta warna diteliti secara estetis. Asas-asas prinsip desain dalam Naskah Indonesia sudah memenuhi asas bentuk logika yang mencakup asas kesatuan, asas tema, asas 
variasi berdasarkan tema, asas keseimbangan, asas evolusi, dan asas tata-jenjang. Unsur atau elemen dasar yang terdapat dalam naskah Indonesia meliputi wujud wayang, figur hewan, dan ikon simbolik lain. Penggunaan warna tidak didominasi warna khusus, baik sebagai latar maupaun ilustrasi utama, penggunaan sistem huruf yang bervariatif membuat keseragaman dan kesatuan secara menyeluruh, dan garis-garis yang digoreskan dipakai menggunakan stilasi ornamen bergaya Jawa, Batak, Bugis dan beberapa daerah lainnya yang mempunyai ciri khas tertentu. Visual yang ada membuat keutuhan dan harmonisasi dengan isi teks yang terdapat pada buku Indonesian Manuscript in Great Britain. Beberapa aplikasi karakter visual dalam media yang diterapkan sangat bervariatif, seperti terdapat pada lembaran kertas, kayu atau papan. Teknik penyelesaian yang bercampur antara penggunaan pensil dan cat air juga menjadi variasi perkembangan visualisasi pada naskah.

Penelitian ini berusaha mengungkap karakter visual yang muncul dalam naskah Indonesia yang terdapat dalam buku The Indonesian Manuscript in Great Britain secara wujud formalistik dan dikaji melalui asas-asas estetis. Kecintaan terhadap budaya dan demi melestarikan artefak asli milik Indonesia disarankan untuk selalu dibangun dan dilakukan. Untuk penelitian berikutnya disarankan dapat mengkaji makna-makna simbolik dari ikon-ikon yang tercipta dalam naskah Indonesia yang secara rapi dan terstruktur didokumentasi pada perpustakaan di luar negeri. Harapannya penelitian ini dapat membuka wawasan dan peluang untuk menjaga dan melestarikan peninggalan sejarah Indonesia.

\section{DAFTAR PUSTAKA}

Fathurahman, O. (2015). Filologi Indonesia: Teori dan Metode. Jakarta: Prenadamedia Group.

Gie, T. L. (2004). Filsafat Keindahan. Edisi kedua. Yogyakarta: Pusat Belajar Ilmu Berguna.

Kumar, A. dan McGlynn, J. H. (1996). Illuminations: The writing Traditions of Indonesia. Jakarta: The Lontar Foundation.

Kusumah, Dloyana, S., dkk. (1997). Indonesia Indah: Aksara. Edisi Sembilan. Jakarta: Yayasan Harapan Kita BP3/TMII.

Damayanti, N. Y. (2008). Karakter Visual Dan Gaya Ilustrasi Naskah Lama Di Jawa Periode 18001920, Jurnal of Visual Art \& Design Vol.2, No.1 Hal 54-71 (ISSN:2338-5480) Institute Teknologi Bandung.

Damayanti, N. Y. dan Suadi, H.. (2007). Ragam dan Unsur Spritualitas pada ilustrasi Naskah Nusantara 1800-1900-an, Jurnal of Visual Art \& Design Vol.1, No.1 Hal 6684 (ISSN:2338-5480) Institut Teknologi Bandung.

Safari, A. O. (2011). Iluminasi Pada Naskah Cirebon, Jurnal Manuskripta Vol.1, No.2 Hal 4357 (ISSN:2252-5343) Masyarakat Pernaskahan Nusantara 